\title{
CENTRE
}

for

ECONOMIC PERFORMANCE

DISCUSSION PAPER NO.376

November 1997

HOW TO COMPETE:

THE IMPACT OF WORKPLACE PRACTICES AND

INFORMATION TECHNOLOGY ON PRODUCTIVITY

S. Black and L. Lynch 


\begin{abstract}
Using data from a unique nationally representative sample of businesses, the Educational Quality of the Workforce National Employers Survey (EQW-NES), matched with the Bureau of the Census' Longitudinal Research Database (LRD), we examine the impact of workplace practices, information technology and human capital investments on productivity. We estimate an augmented Cobb Douglas production function with both cross section and panel data covering the period of 1987S1993 using both within and GMM estimators. We find that what is associated with higher productivity is not so much whether or not an employer adopts a particular work practice, but rather how that work practice is actually implemented within the establishment. We also find that those unionized establishments that have adopted what have been called new or 'transformed' industrial relations practices that promote joint decisionmaking coupled with incentive based compensation have higher productivity than other similar non-union plants, while those businesses that are unionized but maintain more traditional labor management relations have lower productivity. We also find that the higher the average educational level of production workers or the greater the proportion of non-managerial workers who use computers, the higher is plant productivity.
\end{abstract}

This paper was produced as part of the Centre's 


\begin{abstract}
Industrial Relations Programme
HOW TO COMPETE:

THE IMPACT OF WORKPLACE PRACTICES AND INFORMATION TECHNOLOGY ON PRODUCTIVITY
\end{abstract}

Sandra Black and Lisa Lynch 
NOVEMBER 1997 


\author{
Published by \\ Centre for Economic Performance \\ London School of Economics and Political Science \\ Houghton Street \\ London WC2A 2AE \\ (C) S. Black and L. Lynch, 1997 \\ ISBN 0853285608
}




\section{HOW TO COMPETE: \\ THE IMPACT OF WORKPLACE PRACTICES AND INFORMATION TECHNOLOGY ON PRODUCTIVITY}

Sandra Black and Lisa Lynch

Page

1. Introduction 1

2. Background Discussion 4

3. The Data 9

4. The Model 12

5. The Results 16

5.1 Cross Section Estimation 16

5.2 Panel Data Two Step Estimation Based On Within Estimator 20

5.3 Panel Data Two Step Estimation Based On GMM Estimator 21

6. Conclusion 24

Endnotes 25

Tables $\quad 27$

References 33

The Centre for Economic Performance is financed by the Economic and Social Research Council. 


\section{ACKNOWLEDGEMENTS}

Part of the work reported herein was supported under the Education Research and Development Center program, agreement number R117Q00011-91, CFDA 84.117Q, as administered by the Office of Educational Research and Improvement, U.S. Department of Education. This funding was administered through the National Center on the Educational Quality of the Workforce (EQW), University of Pennsylvania. The authors have benefitted from comments by Martin Bailey, Richard Freeman, Dale Jorgenson, John Halitwanger and participants in seminars at the Census Bureau, the London School of Economics, the Institute for Fiscal Studies, and the Universities of Bristol, Essex, Mannheim, Maryland, Oxford, and Warwick. We would especially like to thank Fabio Schiantarelli for his extensive comments on this paper and Steve Bond, Joyce Cooper, Wayne Gray, Arnie Reznek, and Steve Rudolph who provided much assistance on the data used in this project. The findings and opinions expressed in this report do not necessarily reflect the position or policies of OERI, the U.S. Department of Education, the Bureau of the Census, the Federal Reserve Bank of New York, or the Federal Reserve System.

Lisa Lynch is at the Fletcher School of Law \& Diplomacy, Tufts University and is affiliated to the NBER and Centre for Economic Performance. Sandra Black is at the Department of Economics, Harvard University and the Federal Reserve Bank of New York. 


\title{
HOW TO COMPETE: \\ THE IMPACT OF WORKPLACE PRACTICES AND INFORMATION TECHNOLOGY ON PRODUCTIVITY
}

\author{
Sandra Black and Lisa Lynch
}

\section{INTRODUCTION}

How do managerial decisions such as whether or not to adopt a Total Quality Management system or expand an employee involvement program affect labor productivity? Does the implementation of "high performance" workplace practices ensure better firm performance? Does the presence of a union hinder or enhance the probability of success associated with implementing these practices? Do computers really help workers to be more productive? These questions and others have been raised in recent years as many firms have reorganized or re-engineered their work sites from the old Fordist model of work organization to new 'high performance' work systems that decentralize decision-making within a firm. Using data from a unique nationally representative sample of businesses S the Educational Quality of the Workforce National Employers Survey (EQW-NES) $\mathrm{S}$ we begin to examine these and other important questions about the determinants of productivity.

While there have been many studies on the impact of capital investments and $R \& D$ on firm or establishment productivity, until recently there has been very little direct analysis of the impact of workplace practices on productivity. Some of these studies have also been hindered by problems such as low survey response rates, firm level rather than establishment level productivity data, limited workplace practice data, and subjective measures of productivity. Moreover, while there is ample micro-based evidence on the impact of human capital accumulation on individuals' wages, much less is known about the direct effect of human capital on the productivity of businesses. Finally, although there has been some research using firm data on the impact of computers on productivity, these studies have not been able to simultaneously control for workplace practices and human 
capital investments as we will be able to do.

Our work builds upon this research by using a large nationally representative sample of manufacturing businesses. Because of the survey design, we have detailed information on workplace practices (beyond just their incidence), human capital investments, and a measure of the diffusion of computer usage that can be matched with standard cross section and longitudinal measures of inputs and outputs of the production process. More specifically, the EQW-NES provides information on workplace practices such as total quality management systems, benchmarking, the diffusion of computer usage among nonmanagerial employees, recruitment strategies, the use of profit sharing and the extent of employee participation in decision-making. In addition, we have information on the average educational level of the establishment, the numbers of employees trained over two years, the types of training programs offered and where the training took place (on-the-job or off-the-job), along with other characteristics of the business such as whether or not it is unionized, employee turnover, the age of the capital stock, and the demographic composition of the workforce. Finally, one design feature of the EQW-NES is that we are able to match it with the Bureau of the Census' Longitudinal Research Database (LRD) so that we can utilize the panel data nature of the LRD.

We first estimate a standard Cobb Douglas production function with cross section data that is augmented by our measures of workplace practices, information technology, and human capital investments. We then estimate a production function on the LRD panel covering the period of 1987 S1993 using both within and generalized method of moments (GMM) estimators to address omitted variable and endogeneity bias. The average residual over this period is then used as a measure of the establishment fixed effect and is regressed on our measures of workplace practices, human capital investments, diffusion of computer usage and other employee and employer characteristics to determine their association with productivity. In this way we try to see how the information on workplace practices we obtained in our 
survey is related to which businesses did better or worse on average over the period 1988S1993.

We find that workplace practices do matter, no matter how the production function is estimated. However, we find that what is associated with higher productivity is not so much whether or not an employer adopts a particular work practice but rather how that work practice is actually implemented within the establishment. For example, simply adopting a Total Quality Management system has an insignificant or negative impact on productivity unless the proportion of workers involved in regular decision-making within the plant is also high. In other words, it is not so much what you say you do, but how you do it that matters.

We also find important differences across plants on the basis of the type of labor-management relations within the plant. Establishments with more traditional unionized labor management relations with little or no direct participation of employees in decisionmaking have substantially lower productivity than unionized plants that have adopted new workplace practices including incentive based compensation and greater employee participation in decision-making. In addition, these unionized plants perform much better than even nonunion plants that have adopted similar high performance workplace practices.

These findings suggest that establishment practices that encourage workers to think and interact in order to improve the production process are strongly associated with increased firm productivity. We find that the higher the average educational level of production workers within a plant, the more likely the plant has performed better than average over the period 1988S1993. In addition, although the proportion of managerial workers who use computers has no impact on labor productivity, the greater the proportion of non-managerial workers who use computers, the higher is plant productivity. This has important implications concerning the potential impact of government programs that encourage the extension of profit sharing to nonmanagerial employees and employee participation, education, and 
computer literacy. The paper is organized as follows: Section 2 contains a review of the literature on the impact of workplace practices on productivity, Section 3 describes the data used, Section 4 presents the model used for estimation, Section 5 reports results, and Section 6 summarizes the main findings.

\section{BACKGROUND DISCUSSION}

Our paper is not the first to examine the impact of workplace practices on productivity of businesses, but much of the previous work on this topic has been limited in several ways. Some of the most detailed work on the adoption and nature of new workplace practices has been done on a case study basis. This includes work on auto plants by Krafcik (1988) and Womack, Jones and Roos (1991), a paper mill by Ichniowski (1992), two apparel plants by Berg, Appelbaum, Bailey, and Kalleberg (1996), and a regional phone company by Batt (1995). While these studies have provided us with a wealth of information on the chain of events that resulted in the adaptation of new workplace practices, it is difficult to generalize these results to a broader spectrum of the economy. In particular, are the plants that get chosen for a case study successful because of their new workplace practices or some other factor that cannot be controlled for in a case study?

One solution to this problem is to conduct a detailed intraindustry study of the adoption of workplace practices to see their impact on a range of industry specific performance measures. The advantage of intra-industry studies is that one can collect a high degree of detailed information on the variation of practices within a sector and see how they are related to variations in performance. Examples of intra-industry studies include work by Ichniowski, Shaw and Prennushi (1995) and Arthur (1994) on the steel industry, Kelley (1994 and 1996) on the machine tool industry, and Bailey (1993) and Dunlop and Weil (1996) on the apparel industry. By examining human resource practices associated with one specific production process it is possible to greatly reduce problems of underlying heterogeneity of 
production processes. Most of the intra-industry studies conclude that the adoption of a coherent system of new human resource management practices such as flexible job definitions, cross-training, and work teams, along with extensive reliance on incentive pay, results in substantially higher levels of productivity than more traditional human resource management practices (less flexible, close supervision, hourly pay). While these results represent an important contribution to the literature on workplace practices and productivity, it is not easy to generalize these findings for a broader segment of the economy.

Another research strategy is to take a cross section of a more representative sample of firms and examine the impact of workplace practices on broader measures of performance such as productivity or profitability. One example of this strategy is Ichniowski (1990) where he tests the hypothesis that a firm's system of personnel policies can affect its economic performance. To do so, he creates an index of human resource management practices that has a range of $1 \mathrm{S9}$ based on a 11-question survey of manufacturing production workers. These questions measure the incidence of workplace practices such as the existence of formal information sharing programs, formal training programs, merit pay, use of broad job design, and formal grievance procedures. He concludes that there is a correlation between human resource management systems and business performance as measured by labor productivity or Tobin's q. Unfortunately his work is limited by a low overall response rate ( 6 per cent) in the survey from which he draws his subsample of manufacturing firms. As a result, his sample is not representative of manufacturing firms and it is quite small (he has sales/labor ratios for only 126 firms and Tobin's q for just 65 firms). In addition, since the survey only has information on the incidence of workplace practices, he is unable to examine how the diffusion of these practices affects productivity. Finally, using an index of workplace practices makes it difficult to determine the direct impact of implementing a formal training program versus expanding the role of employee participation in decision-making or introducing profit sharing on productivity. 
Huselid (1995) looks at the human resource practices of a crosssection of firms, and Huselid and Becker (1996) use the same data set with an additional year of data. Huselid and Becker extend the concepts developed by Ichniowski and measure factors such as the proportion of the workforce in quality circles or other forms of employee participation, the proportion eligible to receive profit or gainsharing, and the number of hours of training a typical employee will get in a year. They conclude that a one-standard deviation "improvement" in a firm's human resource strategy (based on their index of human resource systems) is associated with a present value gain in cash flow and firm market value of $\$ 15,000 \$ \$ 17,000$ per employee.

Some limitations of this work include a low survey response rate (28 per cent in the cross section analysis and 20 per cent in the panel data), the sample is restricted to publicly held firms with more than 100 employees, and the target respondent is not necessarily the plant or business site manager who actually implements the company human resource policies. In addition, Huselid (1995) and Huselid and Becker (1996) use an index of human resource practices, which leads to ambiguities in the interpretation of the results. The index is not based on conceptual groupings but is the result of statistical clustering. Although it probably makes sense to combine subjective responses that are centered on a particular theme into an index, it is not clear when there are more detailed data on factors such as the proportion of workers involved in decision-making as to why it is necessary to group these responses. Because of the difficulty of interpretation, it seems advantageous to study workplace practices individually.

Nevertheless, there is a burgeoning theoretical and empirical debate on the existence of synergies in bundles of human resource management practices. The theoretical work of Milgrom and Roberts (1995) and Kandel and Lazear (1992) and empirical studies by Huselid (1995), Delaney and Huselid (1996) and Ichniowski et al (1995) are important contributions in this area. Milgrom and Roberts argue that the impact of a system of human resource practices will be greater than 
the sum of its parts because of the synergistic effects of bundling practices together. Kandel and Lazear argue that introducing a profit sharing plan for all workers in a firm may have little or no impact on productivity unless it is linked with other practices that address the inherent free rider problem associated with corporate wide profit sharing plans. The empirical evidence on synergies is mixed, with Huselid and Ichniowski arguing that bundles matter more than individual practices and Delaney and Huselid finding no evidence of bundles. Empirically we have opted to interact a wide range of practices with each other to see if there are interaction effects beyond the own effect of specific HR practices. We believe that this is a less restrictive strategy than arbitrarily grouping our businesses into three or four types of HR practice bundles or using factor analysis to generate an index of HR practices. As Osterman (1994) has shown, in spite of widespread diffusion in the 1980s of new workplace practices, U.S. companies use a range of combinations of workplace practices and as a result are not neatly classified into discrete types.

As part of our analysis of the role of synergies in human resource management practices, we also look at the impact of unions on productivity and how the results are affected by the interaction between the presence of unions and other workplace practices. Theoretically, the presence of unions can have a positive effect on labor productivity because they lower the costs of introducing new workplace practices. This occurs because workers are more willing to participate in employee involvement programs since they feel the union will protect their employment security. Agreements made between managers and workers may not be legally enforceable so the presence of unions, as discussed by Malcomson (1983), can address incentive compatibility problems that may arise at the workplace. In addition, negotiations that management undertakes with workers about the introduction of new workplace practices are less expensive if the company only has to deal with union specialists rather than each individual worker.

On the other hand, unions can lower productivity if they 
constrain the choice set of management and pursue restrictive practices such as over manning rules. Empirically, the evidence on the impact of unions on productivity is mixed. Most empirical work has looked at industry level productivity and union density data or industry specific studies. The range of estimates on the impact of unions on labor productivity runs from minus 3 per cent in Clark (1984) to plus 22 per cent in Brown and Medoff (1978) to no effect in Freeman and Medoff (1984). We try to reconcile these disparate findings by interacting the union status of an establishment with other workplace practices. In this way we try to distinguish between different types of labor management relations $S$ traditional and new $S$ and their impact on labor productivity. The only other paper that has tried to do something similar is by Cooke (1994) where he examines the interaction of union status, profit sharing and employee involvement on productivity in a sample of manufacturing establishments in Michigan in 1989.

Barron et al (1994) and Bishop (1994) have studied the link between human resource practices and productivity but use a subjective measure of productivity rather than output, labor productivity, total factor productivity, or value added. Bartel (1989) uses more objective data (although the response rate of the survey is only 6 per cent) on firm output and sales but uses the Compustat II line of business data set. Unfortunately, examining lines of business can result in some fairly high level of aggregation of both human resource practices and performance measures. For example, in the early 1980s a company like Exxon would be classified as having only two lines of business in the Compustat II data set S petroleum and chemical. Coming up with a summary measure for HRM practices at this level of aggregation may miss important variation across plants or business sites within a firm. It also mixes corporate headquarter practices with what is happening at the point of physical production of a product. More generally, while there is a great degree of heterogeneity across employers in their HRM strategies, there may be almost as much variation in practices within multiple establishment firms. Therefore, conditional on data availability, we believe the preferable level of analysis for the issues we 
wish to examine is at the establishment level.

Most of the micro work on education's impact on individual firm productivity has been more indirect or focused on industry level trends ${ }^{1}$. Researchers have examined the impact of education on wages and from this inferred the effect of education on productivity. Empirical analysis on the returns to schooling suggests that an additional year of post high school education can raise wages of a worker from 5S12 per cent. Therefore, researchers have assumed that productivity increases for a more highly educated workforce are of similar magnitude. Again, one of the features of the EQW-NES is that we are able to construct a measure of the average educational level of an establishment and directly examine its effect on productivity.

Finally, the impact of computers on productivity and wages has been analyzed by several researchers, but nevertheless remains a controversial issue. Research in the 1980s (e.g. Bailey and Gordon (1988)) found little impact of computers on trends in aggregate productivity growth, although more recent work by Oliner and Sichel (1994) argues that this is to be expected given that they represent such a small percentage of the capital stock. However, researchers such as Brynjolfsson and Hitt (1993) who have used more micro-based data have found a positive relationship between computers and productivity. In addition, Alan Krueger (1993) found that workers who worked with computers were paid approximately 15 per cent more than similar workers who did not work with computers. However, none of these papers have the detailed information that we have in the EQW-NES to control for a wider range of factors when examining the impact of computer usage on productivity.

This paper seeks to address many of the limitations in previous work on the impact of workplace practices, human capital, and information technology on productivity. We examine a more objective measure of labor productivity using a data set that is more representative, has a higher response rate than most previous studies on the manufacturing sector, and contains very detailed information on specific employer practices. We allow for a less restrictive bundling of 
human resource management practices, match plant level practices with plant level outcomes, and use both cross section and longitudinal data to estimate production functions.

\section{THE DATA}

In order to understand the nature and importance of our contribution, it is useful to start with a description of the data set on which we base our empirical analysis. The EQW National Employers Survey was administered by the US Bureau of the Census as a telephone survey in August and September 1994 to a nationally representative sample of more than 3,000 private establishments with more than 20 employees. The survey represents a unique source of information on how employers recruit workers, organize work, invest in physical capital, and utilize education and training investments. The survey oversampled establishments in the manufacturing sector and establishments with over 100 employees. Public sector employees, not-for-profit institutions, and corporate headquarters were excluded from the sample. The target respondent in the manufacturing sector was the plant manager and in the non-manufacturing sector was the local business site manager. However, the survey was designed to allow for multiple respondents so that information could be obtained from establishments that kept financial information such as the book value of capital or the cost of goods and materials used in production at a separate finance office (typically at corporate headquarters for multi-establishment enterprises). Computer Assisted Telephone Interviewing (CATI) was used to administer each survey, which took approximately 28 minutes to complete.

The sample frame for the survey was the Bureau of the Census SSEL file, one of the most comprehensive and up-to-date listings of establishments in the United States. While the survey included establishments in both the manufacturing and non-manufacturing sectors, this paper examines responses from manufacturing respondents 
only. This is because we link this survey with the Census Longitudinal Research Database (LRD) that includes longitudinal information for manufacturing establishments only. In other work (Lynch and Black (1995) and Black and Lynch (1996)), we analyze the cross sectional data from the EQW-NES for both manufacturing and nonmanufacturing establishments.

The response rate in the EQW National Employers Survey for manufacturing establishments was 75 per cent, which is substantially higher than most other voluntary establishment surveys. Probit analysis (available from the authors upon request) of the characteristics of nonrespondents indicates that there was no significant pattern at the two digit industry level in the likelihood of participating in the survey. The only businesses more likely not to participate were manufacturing establishments with more than 1000 employees. Of the 1,831 manufacturing establishments who participated in the survey, not all respondents completed all parts of the survey by the interview cutoff date of 1 October 1994. Therefore, the final number of manufacturing establishments in the sample for which all parts of the survey was completed were 1,621 establishments. This represents a 66 per cent overall 'completed' survey response rate.

As mentioned above, we are able to match establishments in our survey to the Longitudinal Research Database (LRD). The LRD, housed at the Center for Economic Studies at the Bureau of the Census, was created by longitudinally linking the establishment level data from the Bureau of the Census' Annual Survey of Manufacturers (ASM). The LRD data include information on shipments, materials, inventories, employment, expenditures on equipment and structures, book values of equipment and structures, and energy use (for more information on the LRD see Davis and Haltiwanger (1991)). Because we are able to match the LRD with the EQW-NES, we can have annual establishment level data on inputs and outputs of production for the manufacturing employers in our survey.

Although we could, in theory, use data from the LRD from as far back as 1972, we restrict our analysis to just those establishments in 
the LRD from 1987 through $1993^{2}$. We believe that this choice is a reasonable compromise between having a sufficiently large number of years of data to obtain an estimate of the establishment fixed effect, yet few enough to allow us to assume that some of the workplace characteristics are more or less constant over this period. Because of this balanced panel restriction, along with problems of missing data, our final estimation sample is reduced to 627 establishments. The LRD is basically the universe of all manufacturing establishments with more than 250 employees but is only a sub-sample of establishments with less than 250 employees. Therefore, by restricting our analysis to employers in the EQW-NES that were in the LRD from 1987 onwards we are more likely to omit smaller establishments and establishments that were 'born' after 1987. However, this does not mean that our sample does not include smaller establishments. In fact, almost 20 per cent of our observations in this restricted sample are on establishments with less than 100 employees. In addition, we are able to compare some of the results in this paper with those obtained using a larger sample that does not impose these restrictions (see Black and Lynch, 1996).

\section{THE MODEL}

We base our empirical analysis of the determinants of establishment productivity on an augmented Cobb Douglas production function containing real sales (Y), labor (L), capital (K), materials (M), and our workplace practices, human capital and information technology variables. We test the restriction implied by constant returns to scale and find that for our data this restriction is always accepted. Therefore, our reported results use the following specification which imposes constant returns to scale (a complete set of all the estimated equations is available from the authors upon request):

$$
\ln (\mathrm{Y} / \mathrm{L})_{\mathrm{i}}=\mathrm{a} \ln (\mathrm{K} / \mathrm{L})_{\mathrm{i}}+\beta \ln (\mathrm{M} / \mathrm{L})_{\mathrm{i}}+\mathrm{d}^{\prime} \mathrm{Z}_{\mathrm{i}}+\mathrm{e}_{\mathrm{i}}
$$


and

$$
\ln (\mathrm{Y} / \mathrm{P})_{\mathrm{i}}=\mathrm{a} \ln (\mathrm{K} / \mathrm{P})_{\mathrm{i}}+\beta \ln (\mathrm{M} / \mathrm{P})_{\mathrm{i}}+? \ln (\mathrm{N} / \mathrm{P})_{\mathrm{i}}+\mathrm{d}^{\prime} \mathrm{Z}_{\mathrm{i}}+\mathrm{e}_{\mathrm{i}}
$$

where $e_{i}$ is an error term and $d^{\prime}$ is a vector of coefficients on $Z_{i}$ which are establishment specific workplace practices and characteristics of employees such as education and turnover. In equation (1) we treat all workers identically and in equation (2) we differentiate between production workers $(\mathrm{P})$ and non-production workers $(\mathrm{N})$.

Before discussing in more detail the nature of our empirical estimation, it is necessary to describe the construction of the input variables derived from the LRD. Since we do not have a measure of the capital stock every year in the LRD we need to construct a measure. We use the standard perpetual inventory method to construct an estimate of the value of the capital stock in each year starting from the book value in a base year and using the information on new investment together with an estimate of the portion of the capital stock that depreciates each year. ${ }^{3}$ We chose the total book value of the capital stock in 1987 as our starting point. We also tried using 1982 as the base year, however, we lose many observations when we do this. In any case, when we do use 1982 as the base year, none of the empirical findings change very much. ${ }^{4}$ In addition, we check the sensitivity of our estimates to the inclusion of end of period or beginning of period values of the capital stock. Again, our empirical results are not very sensitive to this distinction. Generally, we prefer results using the value of the beginning of period capital stock on the assumption that it takes time before new capital becomes productive. Finally, we do not account for the value of assets sold, retired, scrapped or destroyed because these data are not available in the ASM after 1988.

Total sales, capital, and material numbers were all adjusted using deflators from the NBER Productivity Database assembled by Eric Bartelsman and Wayne Gray (1995). These deflators were constructed from 5-digit product deflators from BEA. These are largely created from the Bureau of Labor Statistics' (BLS) industry-based producer 
prices which are extrapolated backwards using the old BLS product prices.

The capital deflator was created by first generating a 3-digit industry real net capital stock value. The 3-digit data are converted to the 4-digit level by assuming that the industry-asset type flows are the same for all 4-digit industries within a 3-digit industry. With this information, 4-digit investment deflators were created for equipment and structures separately. The materials deflator was created by averaging together price deflators for 529 inputs (369 manufacturing industries and 160 non-manufacturing industries), using as weights the relative size of each industry's purchases of that input in the InputOutput Tables. The inflation in materials' prices was calculated as a Tornquist index (weighting each product's inflation rate by the average of the previous and current-year's shares in total materials used).

The energy price deflator is based on each industry's expenditures on six types of energy (electricity, residual fuel oil, distillates, coal, coke and natural gas). These six types of energy represent 94.6 per cent of all energy expenditures by the manufacturing sector in 1976. They were a majority of the energy costs for all but one industry, and over 90 per cent of energy costs for 300 of the industries.

Finally, since the deflator data were unavailable for 1993, we regressed current price levels (using 2- or 3-digit level SIC data, depending upon availability) on the previous year's price level and the current year's producer price index for stage of processing groupings from the BLS. We then generated an imputed value for 1993 deflators using the predicted values from this regression.

In addition to the effect on output of capital, labor and materials using data from the LRD, we also allow productivity to depend upon workplace practices, plant specific human capital measures, the diffusion of information technology, employee turnover rates, age of the establishment, $R \& D$ policy in the firm, age distribution of the capital stock, and other characteristics of the establishments using data from the EQW-NES. In spite of the fact that we are able to control for many more managerial practices than most previous studies on 
productivity, our estimates may still be subject to omitted variable bias (see Griliches and Mairesse 1995) due to unobserved establishments characteristics that we are unable to control for. Although we believe that the detailed information contained in our establishment survey allows us to extract much of the previously unobserved establishment specific effect, one can remove biases due to omitted but time-invariant establishment-specific effects using panel data (see Schmidt (1985) for a discussion on using panel data to estimate firm level efficiency). Consider the following equation:

$$
\mathrm{Y}_{\mathrm{it}}=\mathrm{a}^{\prime} \mathrm{X}_{\mathrm{it}}+\mathrm{d}^{\prime} \mathrm{Z}_{\mathrm{i}}+\mathrm{v}_{\mathrm{i}}+\mathrm{e}_{\mathrm{it}}
$$

where $\mathrm{Y}$ is sales per production worker, $\mathrm{a}^{\prime}$ is a vector of coefficients on capital per production worker, materials per production worker, and the number of non-production workers per production worker, $d$ ' is our vector of coefficients on workplace practices from the EQW-NES survey, $\mathrm{v}_{\mathrm{i}}$ is an unobserved time invariant establishment fixed effect and $\mathrm{e}_{\mathrm{it}}$ is the idiosyncratic component of the error term. If we take deviations from a firm's mean or take first differences of equation (3), all firm observed and unobserved time invariant fixed effects drop out and we can remove the bias in estimating the coefficients in vector $\mathrm{a}^{\prime}$ that occurs because of the omission of the establishment fixed effect. However, this means that we are unable to observe the impact of the observed but time invariant employer fixed effects such as workplace practices and educational quality of the workforce on labor productivity. Therefore, we adopt the following two step procedure. In the first step we use the within estimator to obtain estimates of the coefficients (a') on capital, labor and materials $\left(\mathrm{X}_{\mathrm{it}}\right)$ from the 1988 S1993 LRD panel. Year-industry specific constants are also included in the estimated equation to allow for differential technological progress by industry and control for industry-year specific business cycle effects that lead to differential intensity of use of the factors of production. The use of the within estimator deals with the correlation between the choice of inputs and the firm specific-time 
invariant component of the error term. However, if capital, employment, materials, and output are chosen simultaneously, or if there are measurement errors in the explanatory variables, the within estimator will be inconsistent (see discussion by Griliches and Hausman (1986)). For this reason we have also estimated equation (3) by the Generalized Method of Moments technique (GMM), combining the equation in differences and levels. This approach is an extension of Arellano and Bond (1991) along the lines suggested by Arellano and Bover (1995), and is implemented in the revised version of the DPD program by Arellano and Bond (1988)

Next we generate predicted values of $Y_{i t}-a^{\prime} X_{i t}=d^{\prime} Z_{i}+v_{i}+e_{i t}$ using the within estimator or the GMM estimator of $\mathrm{a}^{\prime}{ }^{6}$. We then average that value over the period 1988S1993 for each business to get an estimate of the firm specific-time invariant component of the residual ${ }^{7}$. We do this for a larger data set than in the second step because we are not constrained to have information on all of the workplace practices in order to do this estimation. By including a larger number of observations we hope to improve the precision of our estimates for capital, labor and materials. In the second step, we regress our average residual on the various human resource management practices, human capital measures, a variable to capture diffusion of information technology, industry dummies, and other worker and employer characteristics we find in the EQW-NES in order to obtain estimates of d'.

One advantage of this two step procedure relative to the estimation of the cross section production functions (which include workplace practices and establishment characteristics) is that we can address the issue of biases in the estimates of the coefficients of capital, labor, and materials due to correlations with the firm specific-time invariant components of the error term, $v_{i}$. The GMM estimator can also address the issue of biases due to correlation with $\mathrm{e}_{\mathrm{it}}$. These advantages complement the fact that the panel allows us to bring more information to bear in estimating capital, labor and materials coefficients. However, biases can still arise in estimating the d's in the 
second step. These biases will be discussed further below.

\section{THE RESULTS}

In this section we discuss the econometric results concerning the effect of workplace practices, establishment and worker characteristics on productivity.

\subsection{Cross Section Estimation ${ }^{8}$}

Table 1 presents our cross section estimation of an augmented Cobb Douglas production function with constant returns to scale (this restriction was tested and accepted). In equation (1) in the table we use the total number of workers as our measure of labor and then in equation (2) we separate employees into production and nonproduction workers. Therefore, the dependent variable in the first regression is the log of annual sales per worker for 1993 while the dependent variable in equations (2) and (3) is the log of annual sales per production worker for 1993. Equation (3) allows for interactions between various workplace practices. The estimated coefficients on capital, labor and materials are consistent with previous estimation using the LRD through 1987 except that the coefficient on capital is rather small. This may be due in large part to measurement error and we return to this issue in Table 3. In terms of the variables we use from our survey, we find that investments in new technology are associated with significantly higher establishment productivity. Although the age of the capital stock appears to have insignificant effects on productivity, the existence of a research and development center within the firm is associated with significantly higher productivity. In addition, the more non-managerial workers who use computers, the higher the establishment's productivity. Interestingly, in results not reported here, the proportion of managers who use computers is never significant in 
any specification we tested.

In Table 1, education has a significant impact on establishment productivity in equation (1) when the total number of workers is used as a measure of labor inputs. The coefficient on average educational level for the establishment suggests that raising the average educational level of the establishment by 10 per cent (approximately one more year of school) would increase productivity by approximately 5 per cent. This is similar to findings reported in Black and Lynch (1996). However, the effect of education disappears when workers are divided into production and non-production workers in equations (2) and (3). In this sample, there is relatively little variation in education once you distinguish between production and non-production workers. Production workers typically have just a high school degree while nonproduction workers have some college. Employers appear to adjust the educational quality of their workforce by changing the mix of production and non-production workers rather than hiring more educated production workers. Since there has been relatively little net new hiring in manufacturing in recent years, this finding makes sense.

None of the training variables we tried to include in our regressions are statistically significant. In previous work (Black and Lynch (1996)), using a larger sample of establishments, we found that the proportion of time spent training workers off-the-job raised establishment productivity in the manufacturing sector. Unfortunately, in the EQW-NES we do not have a measure of the accumulated stock of training for all workers, only training done at two points of time $\mathrm{S}$ 1990 and 1993. This means that our estimates of the impact of training are most likely underestimates of the true returns to training. But given our finding that the proportion of non-managerial workers using computers has a significant and positive relationship to establishment productivity, we conclude that human capital investments can have an important impact on labor productivity. While new entrants into the labor market are more and more likely to have computer skills, new ways will have to be found to help incumbent workers acquire these 
skills either through their employers or off-site at their local community colleges or training institutes.

Workplace practices have very interesting effects on labor productivity. In particular, we find that simply introducing high performance workplace practices is not enough to increase establishment productivity. The increased employee voice that is associated with these practices seems to be a necessary condition to making the practices effective. For example, although almost threequarters of all of the establishments in our sample have some form of a Total Quality Management (TQM) system in place, TQM is not itself associated with higher productivity. Instead, the percentage of workers involved in regular decision-making meetings is positively related to labor productivity. On average, about 54 per cent of employees in our sample are involved in some sort of regular meeting to discuss workplace issues. Benchmarking ${ }^{9}$ and profit sharing for production workers, both considered high performance workplace practices, are also associated with higher establishment productivity, while higher employee turnover is associated with lower establishment productivity.

Given that workplace practices are related to establishment productivity, it is interesting to think about complementarities of these practices. We tried a wide range of interaction effects and found that most were not even remotely significant. However, equation (3) in Table 1 presents results when we interact unionization and TQM, unionization and profit sharing for non-managers, the percentage meeting in groups and profit sharing for non-managers, and the percentage meeting in groups and TQM. When these interactions are included, the own effect of unionization becomes significant and negative while the interactions of unionization and profit sharing for non-managers and unionization and TQM are significant and positive. This indicates that more traditional labor management relations, where employees have little voice in decision-making and pay is not linked to performance, is associated with lower establishment productivity. At the same time, more cooperative unionized labor management relations 
(where employees have a greater role in decision-making but also have part of their compensation linked to firm performance) are associated with higher labor productivity.

Other results of interest that are not reported in Table 1 include the lack of significance of the percentage of employees who are women or minorities. In manufacturing, everything else held constant, we find that there seems to be little evidence of lower productivity associated with hiring a larger proportion of women or minorities. In addition, we find that newer establishments have significantly higher productivity, all else constant, than older establishments.

In Table 2, we take the regression coefficients from equation (3) in Table 1 and present some different prototype plants to see how various combinations of workplace practices are related to labor productivity. We construct a base case which is a non-union multiestablishment plant, has profit sharing for managers but no profit sharing for non-managers, no TQM, no benchmarking, 1 per cent of employees meeting regularly about work issues, 10 per cent of nonmanagerial workers using computers, 1 per cent of employees in selfmanaged teams, zero values for interaction terms and mean values for all remaining continuous variables. We then alter some of the characteristics of this base case to see how labor productivity changes. If we make the plant unionized with no employee involvement, productivity drops by 15 percentage points. If instead we increase the percentage of non-managerial workers using computers from 10 per cent to 50 per cent, labor productivity increases almost 5 percentage points. Introducing workplace practices associated with what have been called 'high performance work systems' has large and positive effects on productivity. If we change the percentage of non-managers using computers to 50 per cent, have 50 per cent of workers meeting to discuss workplace issues regularly, profit sharing for non-managers, 30 per cent of workers in self-managed teams, TQM, and benchmarking, labor productivity increases almost 11 percentage points. Finally, if we introduce all of these 'high performance workplace practices' and make the plant unionized, productivity increases by 20 percentage points 
above the base case. This table helps highlight the synergies of workplace practices. In particular, those unionized firms who have succeeded in moving to a more cooperative labor management relations system which gives employees more voice in decision-making but at the same time links their compensation with performance have higher labor productivity.

\subsection{Panel Data Two Step Estimation Based on Within Estimator}

In this section we discuss how the results in Table 1 alter when we incorporate panel data on establishment inputs and outputs into the estimation to attempt to control for unobserved time invariant characteristics of the establishment. Our first step is the estimation of a simple Cobb Douglas production function with establishment fixed effects using the panel data from the LRD that includes controls for capital, labor, materials, and industry by time dummies. We again test and accept the restriction of constant returns to scale so our dependent variable is sales per production worker.

The estimates from the first stage estimation using the within estimator are reported in Table 3. Again, capital is small although still significant and positive ${ }^{10}$. Since we had to construct a measure of the capital stock there is likely to be significant measurement error in our proxy for the capital stock. Using these first step estimates we then calculated the average residual for each establishment in the sample. The second column in Table 3 contains the second step results from regressing the average residual on various workplace practices and employee characteristics. Again we see that the proportion of nonmanagerial workers using computers has a significant and positive effect on having higher than average productivity over the period 1988S1993. However, production workers' education is now positively related to those businesses that did better on average over this six year period. TQM is negatively associated to the average residual, while benchmarking is positively associated. Unionization itself has no 
significant effect on which businesses did better or worse on average, but the interaction of unionization and profit sharing for non-managers is associated with better than average performance. In addition, we also find that those employers who cite communication skills as a priority in recruitment also did better than average over the period of 1988S1993. These findings are consistent with the idea that increased employee voice is positively related to establishment productivity, and that new forms of labor-management relations are significantly related to better performing businesses.

\subsection{Panel Data Two Step Estimation Based on GMM Estimator}

While the fixed effects estimator corrects for the omitted variable bias associated with unobserved time invariant factors in the cross-section estimation, the fact that current values of capital, labor, and materials are simultaneously determined with output leads to an upward bias of the estimates. However, measurement error in the capital and materials variables may be biasing our first step estimates of the vector of coefficients a' on capital, labor and materials. In order to attempt to correct for this endogeneity bias, we use generalized method of moments (GMM) techniques to instrument for capital, labor, and materials.

It is important to note that if the coefficients in the equation using the within estimator are tainted because of measurement error, we would expect to see larger and more significant coefficients in the GMM first differences estimation. This is in fact what we see for capital. If one calculates what our reported GMM estimates in Table 3 imply about the share of labor (production and non-production workers) in value added (output minus materials costs), we find that labor accounts for two thirds of value added and capital one third. This is consistent with what we see in national income and product accounts. Note that the Hansen-Sargan test of overidentifying restrictions does not suggest misspecification of the model. When we 
look at the second step estimates based the GMM estimation we see a generally similar pattern of results compared to the within estimator or even the cross section estimates presented in Table 1. The only major changes are that the percentage of non-managers using computers becomes insignificant, as does the measure of employee turnover, although the sign and magnitudes are not inconsistent with previous estimates.

While our two-step procedure in Table 3 addresses the biases that may arise in estimating the vector of coefficients a' on capital, labor and materials, it does not address biases that may arise in the second step when we estimate the vector of coefficients d' associated with observed workplace practices and characteristics. These biases may be due to correlations between the second stage regressors and unobserved time invariant plant level characteristics or with the average of the idiosyncratic shocks (since the time period over which we average is relatively short). Although we believe that our vector d' extracts a substantial part of the previously unobserved fixed effect and that most of the endogeneity issues are related to labor, capital and materials, these potential biases may be affecting our estimates of the impact of workplace practices on labor productivity. For example, firms' decisions to adopt particular workplace practices may be related to business performance, although it is unlikely that it will be performance in just one year. If employers decide to adopt a new workplace practice in times of trouble because it becomes less expensive to switch systems (as suggested theoretically by Caballero and Hammour (1994) and shown empirically for a sample of British employers by Nickell et al (1996)), then our coefficients on workplace practices will likely be biased downwards. This would mean that it would be more difficult to find a positive effect of a workplace practice on labor productivity. If instead, employers are more likely to adopt new workplace practices when times are very good, then our coefficients will be biased upwards. We believe that the theoretical and empirical support for this latter view of the world is not very strong. 
An omitted variable that may be correlated with our workplace practices and consequently generate biases is managerial quality. An argument could be that the presence of good managers is more likely to be observed in firms with 'high performance' workplace practices. Therefore, what looks like an effect of workplace practices on productivity is just good management. But if good managers are those who adopt incentive based compensation, get a higher proportion of their workers involved in decision-making, and train a higher proportion of workers to use computers, then the fact that we are able to include these variables explicitly as regressors in our analysis means that it is unlikely that there is much unobserved managerial quality left.

One might think that having a follow-up survey on workplace practices would at least help us address any bias associated with unobserved but time invariant employer fixed effects. Unfortunately, short panels on workplace practices are not going to be a magic elixir. First, workplace practices change very slowly, so if the period of time between surveys is not long enough there may be very few employers who change practices. Second, measurement error affecting workplace practices will bias our coefficients downwards. Huselid and Becker (1996) present estimates on the impact of measurement error on the coefficients on workplace practices on various firm outcome measures for a two period panel of 218 employers. They find large measurement error (some variables containing $30 S 40$ per cent error variance) and when they try to adjust for this they find their corrected coefficients on workplace practices are similar to those found in cross section estimation. In other words, the upward bias associated with omitted employer fixed effects is almost exactly offset in their sample with the downward bias associated with measurement error. Clearly, a long panel on establishments that included repeated information on workplace practices would be preferable so that we could use a GMM estimation procedure as we did on capital, materials and labor to adjust for endogeneity and omitted fixed effects biases. Even though these types of data are unlikely to be produced in the near future, we believe our results shed some light on the impact of workplace practices and 
information technology on productivity. 


\section{CONCLUSION}

New technologies and changing workplace practices have altered the nature and organization of work. There have been many stories in the popular press about the successes associated with the introduction of high performance workplace systems and the revolution computers have caused on the job. At the same time, the gains to completing a college degree relative to a high school diploma have doubled over the past fifteen years in response to what many have argued are the skill demands associated with new technologies and changing work organization. We have tried in this paper to get a better understanding of how workplace practices, human capital investments and information technology are related to establishment productivity. By using a large representative sample of businesses, we have been able to examine these factors on a broader cross section of employers unlike previous studies that have focused on one particular industry, product or even firm.

By relying on detailed measures of human resource practices included on their own and interacted with each other, rather than just using summary indices, we have been able to see that what appears to matter most for productivity is how HR systems are implemented. Adopting a TQM system per se does not raise productivity. Rather, allowing greater employee voice in decision-making is what seems to matter most for productivity. Instituting a profit sharing system has a positive effect on productivity, but only when it is extended to nonmanagerial employees. Finally, those unionized establishments that have adopted what have been called new or 'transformed' industrial relations practices that promote joint decision-making, coupled with incentive based compensation, have higher productivity than other similar non-union plants, while those businesses that are unionized but maintain more traditional labor management relations have lower productivity. 


\section{ENDNOTES}

1. See Jorgenson and Griliches (1967) and Jorgenson, Gallop and Fraumeni (1987) for a discussion of education, labor quality and productivity using industry level data, and the Bureau of Labor Statistics, US Department of Labor (1993) for a discussion about how educational attainment and workforce composition explain patterns of productivity growth from 1948S1990.

2. Note that if an establishment changed ownership it would still be included in the sample.

3. in other words:

$\mathrm{K}_{\mathrm{t}}=\left(1-\mathrm{d}_{\mathrm{t}}\right) \mathrm{K}_{\mathrm{t}-1}+\mathrm{NI}_{\mathrm{t}} \mathrm{S}$ where $\mathrm{K}_{\mathrm{t}}$ is the real end-of-period capital stock, $\mathrm{d}_{\mathrm{t}}$ is the depreciation rate, and $\mathrm{Ni}_{\mathrm{t}}$ is real capital expenditures. The depreciation used is .1331 for machinery and .0343 for buildings. These numbers come from Hulten and Wykoff, 1981.

4. We also tried using the reported book value of the capital stock in each year as our measure of the capital stock. The problem with this measure is that it does not take into account depreciation or price inflation. In addition, in 1989, 1990, 1991, and 1993 the ASM did not include questions about the book value of the capital stock, only new investment. We did try various imputations of these data but the results do not seem very sensitive to the definition of the capital stock.

5. If the error term is white noise one can use levels of capital, labor, materials, and sales lagged at least twice as instruments for the equations in differences. For the equation in levels, differences of these variables lagged at least one period are legitimate instruments under the additional assumption that the correlation between the level of the variables and the firm specific-time invariant component of the error term is constant (see Arellano 
and Bover (1995)). The orthogonality condition associated with the equations in differences and levels are estimated jointly.

6. We also subtract from $Y_{i t}-a^{\prime} X_{i t}$ time by industry dummies.

7. Note that $e_{i t}$ are assumed to be zero mean disturbances so that averaging over time should eliminate (or at least very substantially reduce) its contribution to the residual.

8. Note that the results differ somewhat from those reported in Black and Lynch (1996) because we have restricted the sample to those establishment in the EQW-NES that are also in the LRD from 1987 through 1993.

9. Benchmarking involves setting targets based on other firms successes and attempting to meet these goals. For example, a manufacturer might use a competitor's or even another industry's scrap rate to establish standards for their own scrap rate.

10. The coefficients on capital, materials and non-production workers can not be exactly compared with those in Table 1 since the sample is different (and larger) in the first step in Table 3 than in Table 1. 
TABLE 1

Determinants of Labor ProductivitySCross Section Results

\begin{tabular}{|c|c|c|c|c|}
\hline Variable & Mean & $\begin{array}{c}\text { Eq. } 1 \\
\text { Coefficient } \\
\text { (t-statistic) }\end{array}$ & $\begin{array}{c}\text { Eq. } 2 \\
\text { Coefficient } \\
\text { (t-statistic) }\end{array}$ & $\begin{array}{c}\text { Eq. } 3 \\
\text { Coefficient } \\
\text { (t-statistic) }\end{array}$ \\
\hline Log (Capital/Workers) & & $\begin{array}{l}.025^{*} \\
(1.76)\end{array}$ & $\begin{array}{l}.033 * * \\
(2.24)\end{array}$ & $\begin{array}{l}.034 * * \\
(2.32)\end{array}$ \\
\hline Log (Materials/Workers) & & $\begin{array}{c}.55 * * \\
(29.49)\end{array}$ & $\begin{array}{c}.59 * * \\
(30.01)\end{array}$ & $\begin{array}{c}.59 * * \\
(29.66)\end{array}$ \\
\hline $\begin{array}{l}\text { Log (Non- } \\
\text { production/Production) }\end{array}$ & & - & $\begin{array}{c}.20 * * \\
(12.085)\end{array}$ & $\begin{array}{c}.21 * * \\
(12.21)\end{array}$ \\
\hline \multicolumn{5}{|c|}{ Technology } \\
\hline$\%$ Equip < 1 yr. & $6.9 \%$ & $\begin{array}{c}.0014 \\
(0.763)\end{array}$ & $\begin{array}{c}.0004 \\
(0.222)\end{array}$ & $\begin{array}{l}.0002 \\
(0.11)\end{array}$ \\
\hline$\%$ Equip 1-4 yr. old & $19.6 \%$ & $\begin{array}{l}.0011 \\
(1.49)\end{array}$ & $\begin{array}{l}.0013 \\
(1.53)\end{array}$ & $\begin{array}{c}.001 \\
(1.29)\end{array}$ \\
\hline R\&D Center & .77 & $\begin{array}{c}0.064^{*} \\
(1.74)\end{array}$ & $\begin{array}{c}.06^{*} \\
(1.64)\end{array}$ & $\begin{array}{c}.06 \\
(1.61)\end{array}$ \\
\hline $\begin{array}{l}\% \text { Non-Managers using } \\
\text { Computers }\end{array}$ & $36.01 \%$ & $\begin{array}{l}.0016^{* *} \\
(3.27)\end{array}$ & $\begin{array}{l}.0014^{* *} \\
(2.74)\end{array}$ & $\begin{array}{l}.0012 * * \\
(2.42)\end{array}$ \\
\hline \multicolumn{5}{|c|}{ Worker Characteristics } \\
\hline Log (Average Education) & 2.54 & $\begin{array}{c}.50^{*} \\
(1.91)\end{array}$ & - & - \\
\hline $\begin{array}{l}\text { Log (Avg Ed non-production } \\
\text { workers) }\end{array}$ & 2.68 & - & $\begin{array}{c}.28 \\
(1.40)\end{array}$ & $\begin{array}{c}.28 \\
(1.41)\end{array}$ \\
\hline $\begin{array}{l}\text { Log(Avg Ed Production } \\
\text { Workers) }\end{array}$ & 2.51 & - & $\begin{array}{l}.18 \\
(0.56)\end{array}$ & $\begin{array}{c}.23 \\
(0.74)\end{array}$ \\
\hline Turnover (\% ees < year) & $9.9 \%$ & $\begin{array}{l}-.003 * * \\
(-2.16)\end{array}$ & $\begin{array}{l}-.002 \\
(-1.27)\end{array}$ & $\begin{array}{l}-.002 \\
(-1.49)\end{array}$ \\
\hline
\end{tabular}

Use of High Performance Work Systems

$\begin{array}{lcccc}\text { TQM } & .73 & -.040 & -.03 & -.041 \\ & & (-1.159) & (-0.78) & (-1.172) \\ \text { Benchmarking } & .48 & .051 * * & .045 & .04 \\ & & (1.96) & (1.47) & (1.23) \\ \text { Number of Managerial Levels } & 2.9 & .002 & .003 & .002 \\ & & (0.29) & (0.39) & (0.28)\end{array}$




\begin{tabular}{lcccc}
\hline \hline Variable & Mean & $\begin{array}{c}\text { Eq. 1 } \\
\text { Coefficient } \\
\text { (t-statistic) }\end{array}$ & $\begin{array}{c}\text { Eq. 2 } \\
\text { Coefficient } \\
\text { (t-statistic) }\end{array}$ & $\begin{array}{c}\text { Eq. 3 } \\
\text { Coefficient } \\
\text { (t-statistic) }\end{array}$ \\
\hline \# employees per supervisor & 25.42 & -.0002 & .0002 & .0002 \\
& & $(-0.27)$ & $(0.25)$ & $(0.36)$ \\
$\begin{array}{l}\text { \% workers in self-managed } \\
\text { teams }\end{array}$ & $14.6 \%$ & .0006 & .0006 & .0007 \\
\hline
\end{tabular}

\section{Employee Voice}

\begin{tabular}{lcccc} 
Unionized & .50 & .03 & .013 & $-.15^{* *}$ \\
& & $(0.907)$ & $(0.39)$ & $(-2.22)$ \\
$\begin{array}{l}\text { \% Workers meeting regularly } \\
\text { in Groups }\end{array}$ & $53.9 \%$ & $.0007^{*}$ & $.0006^{*}$ & .0002 \\
& & $(1.93)$ & $(1.68)$ & $(0.20)$ \\
\hline & \multicolumn{2}{c}{ Profit Sharing } & \\
Managers and Supervisors & .78 & -.03 & -.05 & -.05 \\
& & $(-0.64)$ & $(-1.06)$ & $(-1.09)$ \\
Production/Clerical/Technical & .63 & .054 & $.07 *$ & .02 \\
& & $(1.41)$ & $(1.71)$ & $(0.26)$ \\
\hline
\end{tabular}

\section{Recruitment Strategies}

\begin{tabular}{lcccc}
$\begin{array}{l}\text { Grades a top priority in } \\
\text { recruitment }\end{array}$ & 0.21 & -.013 & -.015 & -.018 \\
$\begin{array}{l}\text { Communication a top priority } \\
\text { in recruitment }\end{array}$ & 0.74 & $.0 .377)$ & $(-0.40)$ & $(-0.49)$ \\
\hline
\end{tabular}

\section{Interaction Terms}

\begin{tabular}{|c|c|c|c|c|}
\hline $\begin{array}{l}\text { union*profit sharing for } \\
\text { non-managerial workers }\end{array}$ & 0.28 & - & - & $\begin{array}{l}.133^{* *} \\
(2.11)\end{array}$ \\
\hline union*tqm & 0.37 & - & - & $\begin{array}{l}.11^{*} \\
(1.68)\end{array}$ \\
\hline $\begin{array}{l}\% \text { meet*profit sharing for non- } \\
\text { managerial workers }\end{array}$ & 35.44 & - & - & $\begin{array}{l}-.0004 \\
(-.052)\end{array}$ \\
\hline$\%$ meet $*$ tqm & 42.61 & - & - & $\begin{array}{c}.001 \\
(1.25)\end{array}$ \\
\hline $\mathrm{N}=$ & 627 & 627 & 627 & 627 \\
\hline Adjusted $R^{2}=$ & & 0.78 & 0.84 & 0.84 \\
\hline
\end{tabular}

Note: t-statistics in parenthesis. ** denotes significant at the 5 per cent level and $*$ denotes significant at the 10 per cent level. Estimated equations also includes a constant term, 2 digit SIC industry controls, age of the establishment, a dummy if the establishment is part of a multiple-establishment firm, the percentage of women employees, the percentage of minority employees, proportion of training done in-house, and a dummy variables if the primary product is exported. 


\section{Table 2: \% Change in Labor Productivity From Base Case}

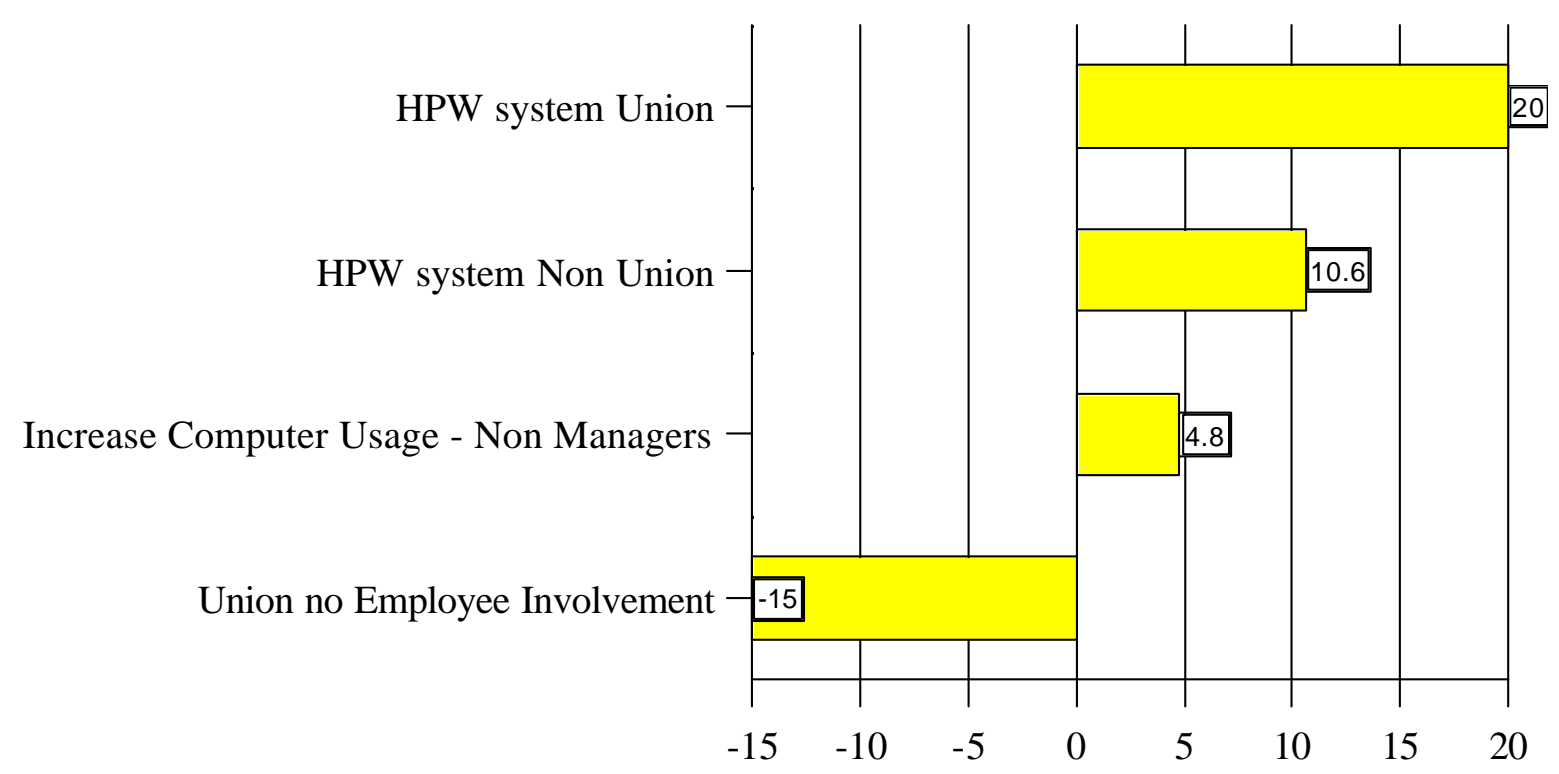

\section{Notes:}

Base Case: Non union, multi establishment plant, profit sharing for managers, no profit sharing for non-managers, no TQM, no benchmarking, $1 \%$ employees meeting regularly about work issues, $10 \%$ nonmanagerial workers using computers, $1 \%$ employees in self-managed teams, zero values for interaction terms and mean values for all remaining continuous variables.

Increase Computer Usage: Base case but increase to 50\% non managers using computers in their job.

HPW system: Base case but $50 \%$ of non-managers using computers, $50 \%$ of workers meeting to discuss workplace issues regularly, profit sharing for non-managers, $30 \%$ of workers in selfmanaged teams, TQM, and benchmarking. 


\section{TABLE 3 \\ Determinants of Labor Productivity 198851993 \\ 2-Step Estimates Using Within and GMM Estimators in the First \\ Step}

(t-statistics in parenthesis)

Within Estimator

GMM Estimator

\begin{tabular}{|c|c|c|c|c|}
\hline & First Step & Second Step & First Step & $\begin{array}{c}\text { Second } \\
\text { Step }\end{array}$ \\
\hline Dependent Variable: & $\begin{array}{l}\text { sales/ } \\
\text { prod. ee }\end{array}$ & \multirow[t]{6}{*}{$\begin{array}{c}\text { avg. residual } \\
1988 S 93\end{array}$} & $\begin{array}{l}\text { sales/ } \\
\text { prod. ee }\end{array}$ & $\begin{array}{l}\text { avg. } \\
\text { residual }\end{array}$ \\
\hline Independent Variables: & & & & $1988 S 93$ \\
\hline Log (Capital/production Workers) & $\begin{array}{l}.03 * * \\
(3.16)\end{array}$ & & $\begin{array}{l}.18^{* *} \\
(4.24)\end{array}$ & \\
\hline Log (Materials/Production Workers) & $\begin{array}{c}0.61 * * \\
(58.54)\end{array}$ & & $\begin{array}{l}.42 * * \\
(9.38)\end{array}$ & \\
\hline \multirow[t]{2}{*}{ Log (Non-production/Production) } & $\begin{array}{l}.07 * * \\
(7.47)\end{array}$ & & $\begin{array}{l}.15^{* *} \\
(4.36)\end{array}$ & \\
\hline & & & $\begin{array}{c}\text { Sargan } \\
\text { test } \\
=44.8 \\
{[\mathrm{p}=.25]}\end{array}$ & \\
\hline
\end{tabular}

Technology

$\%$ Equip $<1$ yr.

.0001

.0009

$(0.05)$

$(0.48)$

$\%$ Equip 1S4 yr. old

.001

.001

(1.41)

R\&D Center

.05

.05

(1.33)

(1.21)

$\%$ Non-Managers using Computers

$.0015^{* *}$

.0007

(2.98)

(1.38)

\section{Worker Characteristics}

Log (Avg Ed non-production workers)

Log(Avg Ed Production Workers) 


\begin{tabular}{|c|c|c|c|c|}
\hline \multicolumn{5}{|l|}{ (t-statistics in parenthesis) } \\
\hline & \multicolumn{2}{|c|}{ Within Estimator } & \multicolumn{2}{|c|}{ GMM Estimator } \\
\hline & First Step & Second Step & First Step & $\begin{array}{l}\text { Second } \\
\text { Step }\end{array}$ \\
\hline Turnover ( $\%$ ees < year) & & $\begin{array}{l}-.003 * * \\
(-2.44)\end{array}$ & & $\begin{array}{c}-.002 \\
(-1.34)\end{array}$ \\
\hline \multicolumn{5}{|c|}{ Use of High Performance Work Systems } \\
\hline TQM & & $\begin{array}{l}-.097 * \\
(-1.63)\end{array}$ & & $\begin{array}{l}-.15^{* *} \\
(2.31)\end{array}$ \\
\hline Benchmarking & & $\begin{array}{l}.055^{*} \\
(1.83)\end{array}$ & & $\begin{array}{l}.06^{*} \\
(1.75)\end{array}$ \\
\hline Number of Managerial Levels & & $\begin{array}{l}-.001 \\
(-0.17)\end{array}$ & & $\begin{array}{c}-.008 \\
(-1.13)\end{array}$ \\
\hline \# employees per supervisor & & $\begin{array}{l}-.001^{*} \\
(-1.70)\end{array}$ & & $\begin{array}{l}-.0004 \\
(-0.53)\end{array}$ \\
\hline$\%$ workers in self-managed teams & & $\begin{array}{l}-.000 \\
(-0.07)\end{array}$ & & $\begin{array}{l}.0002 \\
(0.35)\end{array}$ \\
\hline \multicolumn{5}{|c|}{ Employee Voice } \\
\hline Unionized & & $\begin{array}{c}-.04 \\
(-0.58)\end{array}$ & & $\begin{array}{l}-.11 \\
(-1.6)\end{array}$ \\
\hline$\%$ Workers meeting regularly in Groups & & $\begin{array}{l}.0007 \\
(0.97)\end{array}$ & & $\begin{array}{l}.0001 \\
(0.91)\end{array}$ \\
\hline \multicolumn{5}{|c|}{ Profit Sharing } \\
\hline Managers and Supervisors & & $\begin{array}{c}-.04 \\
(-0.84)\end{array}$ & & $\begin{array}{c}-.07 \\
(-1.46)\end{array}$ \\
\hline Production/Clerical/Technical & & $\begin{array}{c}.009 \\
(0.13)\end{array}$ & & $\begin{array}{c}.02 \\
(0.32)\end{array}$ \\
\hline \multicolumn{5}{|c|}{ Recruitment Strategies } \\
\hline Grades a top priority in recruitment & & $\begin{array}{l}-.008 \\
(-0.57)\end{array}$ & & $\begin{array}{c}-.02 \\
(-1.24)\end{array}$ \\
\hline $\begin{array}{l}\text { Communication a top priority in } \\
\text { recruitment }\end{array}$ & & $\begin{array}{l}.044 * * \\
(2.51)\end{array}$ & & $\begin{array}{c}.04^{*} \\
(1.90)\end{array}$ \\
\hline \multicolumn{5}{|c|}{ Interaction Terms } \\
\hline $\begin{array}{l}\text { union*profit sharing for non-managerial } \\
\text { employees }\end{array}$ & & $\begin{array}{l}.13^{* *} \\
(2.11)\end{array}$ & & $\begin{array}{l}.17 * * \\
(2.60)\end{array}$ \\
\hline
\end{tabular}




\begin{tabular}{|c|c|c|c|c|}
\hline \multicolumn{5}{|l|}{ (t-statistics in parenthesis) } \\
\hline & \multicolumn{2}{|c|}{ Within Estimator } & \multicolumn{2}{|c|}{ GMM Estimator } \\
\hline & First Step & Second Step & First Step & $\begin{array}{l}\text { Second } \\
\text { Step }\end{array}$ \\
\hline union*tqm & & $\begin{array}{c}.03 \\
(0.47)\end{array}$ & & $\begin{array}{c}.07 \\
(1.05)\end{array}$ \\
\hline $\begin{array}{l}\% \text { meet }^{*} \text { profit sharing for non- } \\
\text { managerial workers }\end{array}$ & & $\begin{array}{l}-.0009 \\
(-1.27)\end{array}$ & & $\begin{array}{l}-.0006 \\
(-0.81)\end{array}$ \\
\hline$\%$ meet*tqm & & $\begin{array}{l}.0006 \\
(0.77)\end{array}$ & & $\begin{array}{c}.001 \\
(1.46)\end{array}$ \\
\hline $\mathrm{N}$ for the First Stage $=984$ & $\mathrm{~N}$ for the $\mathrm{Se}$ & ad Stage $=627$ & & \\
\hline Adjusted $\mathrm{R}^{2}=$ & & 0.24 & & 0.09 \\
\hline
\end{tabular}

Note: T-statistics in parenthesis. $* *$ denotes significant at the 5 per cent level and $*$ denotes significant at the 10 per cent level. First stage estimation also includes a constant term, year dummies, and 2 digit SIC industry controls interacted with the year dummies. Second stage equations also include a constant term, 2 digit SIC industry controls, age of the establishment, a dummy if the establishment is part of a multiple-establishment firm, the percentage of women employees, the percentage of minority employees, proportion of training done in-house, and a dummy variables if the primary product is exported. Appropriately lagged values of capital, labor, materials, and sales are used as instruments for the GMM estimator. The Sargan test is distributed as ? ${ }^{2}$ with degrees of freedom equal to the number of instruments minus the number of estimated coefficients. 


\section{REFERENCES}

Arellano, M. and S. Bond (1988), 'Dynamic Panel Data Estimation using DPD S A Guide for Users', Institute for Fiscal Studies Working Paper No.88/15.

Arellano, M. and S. Bond (1991), 'Some Tests of Specification for Panel Data: Monte Carlo Evidence and a Application to Employment Equations,' Review of Economic Studies, Vol.58, pp.277S297.

Arellano, M. and O. Bover (1995), 'Another Look at the Instrumental Variable Estimation of Error-Components Models', Journal of Econometrics, Vol.68, pp.29S51.

Arthur, J. (1994), 'Effects of Human Resource Systems on Manufacturing Performance and Turnover', Academy of Management Journal, Vol.37, pp.670S87.

Bailey, M. and R. Gordon (1988), 'The Productivity Slowdown, Measurement Issues and the Explosion of Computer Power,' Brookings Papers on Economic Activity, Vol.19, No.2, pp.347S420.

Bailey, T. (1993), 'Organizational Innovation in the Apparel Industry', Industrial Relations, Vol.32, pp.30S48.

Barron, J., M. Berger and D. Black (1994), 'How well do we measure training?', Journal of Labor Economics, forthcoming.

Bartel, A. (1992), 'Productivity Gains from the Implementation of Employee Training Programs', NBER Working Paper No.3893.

Bartel, A. (1989), 'Formal Employee Training Programs and Their 
Impact on Labor Productivity: Evidence from a Human Resource Survey', NBER Working Paper No.3026.

Bartelsman, E. J. and W. Gray (1995), 'The NBER Manufacturing Productivity Database', unpublished paper, Board of Governors of the Federal Reserve System (January).

Batt, R. (1995), 'Performance and Welfare Effects of Work Restructuring: Evidence from Telecommunications Services', Ph.D. dissertation, MIT Sloan School of Management, Cambridge, MA.

Berg, P., E. Appelbaum, T. Bailey, and A. Kalleberg (1996), 'The Performance Effects of Modular Production in the Apparel Indusindustrial Relations, Vol.35, pp.356S373.

Bishop, J. (1994), 'The Impact of Previous Training on Productivity and Wages', in L. Lynch (ed), Training and the Private Sector: International Comparisons, University of Chicago Press: Chicago.

Black, S. E. and L. M. Lynch (1996), 'Human Capital Investments and Productivity', American Economic Review, May.

Brown, C. and Medoff, J. (1978), 'Trade Unions in the Production Process', Journal of Political Economy, Vol.86, pp.355S78.

Brynjolfsson, E. and L. Hitt (1993), 'New Evidence on the Returns to Information Systems', Working Paper, Sloan School of Management, MIT.

Bureau of Labor Statistics, US Department of Labor (1993), Labor Composition and U.S. Productivity Growth, 1948S90, Bulletin 2426, US Government Printing Office, December. 
Caballero, R. and M.L. Hammour (1994), 'The Cleansing Effects of Recessions', American Economic Review, Vol.84, pp.1350S68.

Clark, K. B. (1984), 'Unionization and Firm Performance: The Impact on Profits, Growth, and Productivity', American Economic Review, Vol.74, December, pp.8935919.

Cooke, W. (1994), 'Employee Participation Programs, Group-Based Incentives, and Company Performance: A Union-Nonunion Comparison', Industrial and Labor Relations Review, Vol.47, pp.594S609.

Davis, S. and J. Haltiwanger (1991), 'Wage Dispersion Between and Within US Manufacturing Plants: 1963S1986', Brookings Papers on Economic Activity; Microeconomics.

Delany, J. and Huselid, M. (1996) 'The Impact of Human Resource Management Practices on Perceptions of Performance in ForProfit and Nonprofit Organizations', Academy of Management Journal, in press.

Dunlop, J. and Weil, D. (1996) 'Diffusion and Performance of Modular Production in the U.S. Apparel Industry', Industrial Relations, Vol.35, July, pp.334S354.

Freeman, R. and J. Medoff (1984), What Do Unions Do?, Basic Books: New York.

Griliches, Z. and J. A. Hausman (1986), 'Errors in Variables in Panel Data', Journal of Econometrics, Vol.31, pp.93S118.

Griliches, Z. and J. Mairesse (1995), 'Production Functions: The Search for Identification', NBER Working Paper No.5067. 
Hulten, C. and F. Wykoff (1981), 'Measurement of Economic Depreciation', in C.R.Hulten (ed), Depreciation, Information, and the Taxation of Income from Capital, Washington, D.C., Urban Institute.

Huselid, M. A. (1995), 'The Impact of Human Resource Management Practices on Turnover, Productivity, and Corporate Financial Performance', Academy of Management Journal, Vol.38 No.3, pp.635S672.

Huselid, M. A. and B. E. Becker (1996), 'High Performance Work Systems and Firm Performance: Cross-Sectional Versus Panel Results', Industrial Relations, Vol.35, pp.400S422.

Ichniowski (1990), 'Human Resource Management Systems and the Performance of U.S. Manufacturing Businesses', NBER Working Paper No.3449.

Ichniowski (1992), 'Human Resource Practices and Productive LaborManagement Relations', in D. Lewin, O. Mitchell, and P. Sherer (eds), Research Frontiers in Industrial Relations and Human Resources, pp.239S271.

Ichniowski, K. Shaw and G. Prennushi (1995), 'The Effects of Human Resource Management Practices on Productivity', NBER Working Paper No.5333, November.

Jorgenson, D. and Griliches, Z. (1967), 'The Explanation of Productivity Change', Review of Economic Studies, Vol.34, pp.249S283.

Jorgenson, D., F. Gallop and B. Fraumeni (1987), Productivity and U.S. Economic Growth, Harvard University Press. 
Kandel, E. and E. Lazear (1992), 'Peer Pressure and Partnerships', Journal of Political Economy, Vol.100, pp.801S817.

Kelley, M. (1994), 'Information Technology and Productivity: The Elusive Connection', Management Science, Vol.40, pp.1406S25.

Kelley, M. (1996), 'Participative Bureaucracy and Productivity in the Machined Products Sector', Industrial Relations, Vol.35, pp.374S399.

Krafcik, J. (1988), 'Triumph of the Lean Production System', Sloan Management Review, Vol.30, pp.41S52.

Krueger, A. (1993), 'How Computers Have Changed the Wage Structure: Evidence from Micro Data, 1984S1989', Quarterly Journal of Economics, Feb. pp.33S60.

Lynch, L. M. (1995), 'A Needs Analysis of Training Data: What do we want, what do we have, can we ever get it?', in J.Haltiwanger, M. Manser and R. Topel (eds), Labor Statistics Measurement Issues, NBER/University of Chicago Press, forthcoming.

Lynch, L. M. and S. E. Black (1995), 'Beyond the Incidence of Training: Evidence from a National Employers Survey', NBER Working Paper No.5231.

Malcomson, J. (1983), 'Trade Unions and Economic Efficiency', Economic Journal, Vol.93, pp.50S65.

Milgrom, P. and J. Roberts (1995), 'Complementarities and Fit: Strategy, structure and organizational change in manufacturing', Journal of Accounting and Economics, Vol.19. pp.179S208.

Nickell, S., D. Nicolitsas and M. Patterson (1996), 'Does Doing Badly 
Encourage Management Innovation?', Oxford Institute for Economics and Statistics Working Paper, August.

Oliner, S. and D. Sichel (1994), 'Computers and Output Growth Revisited: How Big is the Puzzle?', Brookings Papers on Economic Activity, No.2, pp.273S317.

Osterman, P. (1994), 'How Common is Workplace Transformation and Who Adopts It?', Industrial and Labor Relations Review, Vol.47, No.2, January, pp.173S187.

Schmidt, P. (1985), 'Frontier Production Functions: A Review', Econometric Reviews, No.4.

Womack, J., D. Jones and D. Roos (1991), The Machine that Changed the World, Rawson/Macmillan: New York. 